Article

\title{
Jewish heterosexuality, queer celibacy? Alfric translates the Old Testament priesthood
}

\section{Mo Pareles}

Department of English, University of British Columbia, Vancouver, BC V6T 1Z1, Canada.

\begin{abstract}
This essay argues that Ælfric's discussion of priestly marriage demonstrates an Anglo-Saxon articulation of the difference between Jews and Christians as sexual difference. Ælfric represents temporally distant Biblical Jews as embodying a kinship-based heterosexuality that has been superseded by and is now opposed by Christian chastity and asexual reproduction. This supersession operates through linguistic as well as temporal translation; Ælfric transmutes ritual Jewish purity into Christian sexual purity by translating the Vulgate's mundus and immundus, which gloss Old Testament טָמֵא and uncloene [in Ælfric's context, generally 'chaste' and 'unchaste']. Terms from the Hebrew Bible that, when translated into Greek and Latin, assume equivalence to New Testament terms for spiritual purity thus undergo a further conversion in the work of Ælfric, who diverges from other Old English writers in linking the word claene not only with the Old Testament but also, specifically, with Jewish sexuality. Ælfric’s linguistic choices forge a largely fictive continuity between Jewish and Christian sexual purity systems, while also authorizing Christianity's break from Jewish mores.
\end{abstract}

postmedieval: a journal of medieval cultural studies (2017). 8, 292-306. doi:10.1057/s41280-017-0058-y

Christians and Jews have sometimes articulated their difference in sexual terms. As Steven F. Kruger notes of this nexus of identifications, 'The means for constructing sexual difference and those for defining religious, (quasi-)racial 
otherness are [...] often parallel and intertwined' (Kruger, 2006, 88). Kruger, Daniel Boyarin, and others have traced the use of Jews, especially the figure of the circumcised, nonviolent Jewish man, as abject others in the establishment of Christian heterosexuality, particularly heterosexual masculinity. ${ }^{1}$ In these analyses, which examine material from the late antique, late medieval and early modern periods, Jews thus figure as 'queers' vis-à-vis Christian heterosexuals. This alignment rests on simple grounds: each religion structures its imaginary community around a sanctified system of sexual regulation that not only overlaps with but also at times proves incommensurate with the other. In this essay, I argue that Anglo-Saxon Benedictine culture demonstrates an early medieval English articulation of the difference between Jews and Christians as a sexual difference. In a nearly inverse dynamic to that traced by Kruger and Boyarin, temporally distant Biblical Jews represent a kinship-based heterosexuality that has been superseded by and is now opposed by Christian chastity and asexual reproduction.

In two exhortations that nearly bookend Anglo-Saxon monastic literary culture, Aldhelm of Malmesbury's late seventh-century De virginitate and Ælfric of Eynsham's early eleventh-century First Old English Letter for Wulfstan, Benedictine writers use the imaginary temporal difference between Jews and Christians to propose chastity as a desirable alternative to heterosexuality. In culturally and linguistically translating the matter of the Old Testament's married priesthood for a celibate Anglo-Saxon audience, Ælfric advances a case that is particularly intelligible through the lens of queer theory: heterosexuality is an outmoded form of kinship and affectivity to which the community need no longer be bound.

In discussing sexuality, I use Carol Braun Pasternack's definition of sex as 'practices related to procreation, whether those practices promote or deny procreation, and sexuality as an identity linked to an array of such practices [...] including those practices that do not further reproduction, such as chastity and homosexuality' (Pasternack, 2004, 96, 96n15). I use the term 'heterosexuality' in premodern contexts to refer to the social institutions and intimate practices (marriage; procreation, defined as legitimate or illegitimate; sexual relations between men and women, defined as marital, premarital, or extramarital) that link (and naturalize the links among) sexuality, binary gender roles, procreation, family and kinship, lineage and legacy, status and value of women, and property transfer. When discussing chastity and celibacy, I use Benjamin Kahan's concept of celibacy 'primarily as a coherent sexual identity rather than as a "closeting" screen for another identity,' both because this more accurately reflects medieval sexual categories and because it is no longer useful or radical to reduce 'sexuality' to the gender configurations of sexual pairs (Kahan, 2013, 2).
1 See Boyarin (1997), esp. 1-13, 208216. 


\section{Monasticism as a Queer Mode of Life}

Late twentieth- and early twenty-first-century critiques of heterosexuality have posed queer models of affiliation and reproduction as alternatives to the heterosexual model of reproductive kinship. Gilles Deleuze and Félix Guattari aim to 'conceive of a peopling, a propagation, a becoming that is without filiation or hereditary production,' which operates through unexpected and multiplying lines of desire akin to the spread of disease (Deleuze and Guattari, 2004, 241). They contrast 'filiation' through reproduction to stranger, less predictable, and less heterosexual means of multiplication. I appropriate the structure of this distinction in discussing sexualities in early medieval Christianity. Medieval monastic writers do not, of course, share the motives of twenty-first-century critics such as Lee Edelman, who criticizes the 'reproductive futurism' in which the valorization of heterosexual reproduction guarantees a cycle in which 'the future is mere repetition and just as lethal as the past,' or of Roderick A. Ferguson, Lauren Berlant, and others who note the role of the heterosexual family in reproducing capitalism and white supremacy in North America (Edelman, 2004, 2, 31; Ferguson, 2004; Berlant, 1997). That is, they do not share these critics' investment in progressive politics and sexual freedom. But they do share a suspicion of heterosexuality as a worldly practice that reproduces a detrimental fixation on material investments, that inhibits the expansion of care outside the family circle, and that keeps women and men leashed to their gendered bodies. This Christian critique of the heterosexual family dates to Paul, whose rejection of 'Israel in the flesh' for 'Israel in the spirit' Boyarin persuasively interprets as a statement precisely on the ethnocentric limitations of heterosexual kinship systems. To Paul, argues Boyarin, universality demands a rejection of this form of kinship, even if rejecting ethnocentricity, sex, and sexuality also effectively devalues both the Jewish and the feminine elements it ostensibly subsumes (Boyarin, 1994, esp. 57-85, 180-200). The Benedictine writers further develop Pauline and patristic ideas in order to criticize the theory and practice of heterosexuality and to offer chastity as a preferable alternative orientation.

Monastic celibacy offers a robust alternative to heterosexual kinship by providing fraternal, reproductive, and temporal structures that disrupt and attempt to replace those of the sexually reproductive family. Monasticism adopted, as Carol Braun Pasternack observes, a patristic 'devaluation of procreative sexuality and the related families [...] and the absorption of the individual into the structures of the Church as if into an alternative family' (Pasternack, 2004, 94). These 'alternative' familial structures, in theory, severed and replaced both the generative ('procreative sexuality') and affiliative ('related families') connections of hetero-patriarchal family life. In practice, familial bonds both competed with and complemented monastic kinship ties; Lisa $M$. C. Weston's study of amicitia in Anglo-Saxon nuns' letters, for instance, 
demonstrates that Leoba calls upon both spiritual and secular kinship ties to address Boniface, and that Eangyth, mother of many spiritual daughters, shares a privileged bond with Heaburg, who is also her biological child (Weston, 2011).

Monastic affiliation also qualifies as a non-heterosexual 'mode of life' in the sense that Michel Foucault uses this term. Foucault argues for a 'homosexual mode of life' defined neither by identity politics nor by genital sexuality but by the multiplication and intensification of friendships among men. Monasticism is one potential answer to Foucault's question: 'how is it possible for men to be together? to live together, to share their time, their meals, their room, their leisure, their grief, their knowledge, their confidences?' (Foucault, 1996, 309). The Regularis Concordia, which supplemented the Benedictine Rule in rigorously governing the schedule of English monastic life, in fact provides specific and detailed answers to each of these questions, describing how monks are to sleep and eat communally, to avoid the temptations of intimacy with women and youth, to mourn, and to teach one another and avoid gossiping. Sharing time emerges as the rule's greatest concern: to be, with brethren, 'united in the fellowship of the monastic life' ['unitus in ordinis communione'] (Symons, $1953, \S 67)$ - the words with which a monk is eulogized - is to be occupied night and day in highly ritualized communal activity.

In monastic life, relations within the fellowship are ethically central and have explicitly taken the place of external relationships. Foucault's question echoes the debate within early medieval monasticism about the propriety of intense friendships between monks, typified on the one hand by Ælred of Rievaulx, whose work glorifies spiritual love between men, and on the other by the Benedictine Rule, which forbids close relationships on the grounds that they subvert order and equality (Venarde, 2011, see in particular $\S \S 2,22,69$ ). As Saltzman notes, 'Kinship - a tie that for the Anglo-Saxons was of utmost importance [...] must be severed upon entering the monastery, forming the monks into a homogeneous community of spiritual brothers, united under a spiritual father. Hence, Benedict foresees one monk defending his blood-kin or friend (though he avoids this word) as a devastating act against the equilibrium of solitude and community' (Saltzman, 2011, 260, 258-263). ${ }^{2}$ As Foucault observes of this tension, 'The institution is caught in a contradiction; affective

2 See also Jaeger (1999), 31-32. intensities traverse it which at one and the same time keep it going and shake it up' (Foucault, 1996, 309). The most intense, contested, and discussed human affective investments of this life are primarily same-sex, regardless of sexual practice. The resonance of the problems of early medieval European monastic life in twentieth-century queer theory reveals monasticism as a non-heterosexual, ideologically driven 'mode of life.'

Thus monastic life replaces kinship by providing alternative structures of fraternity and filiation and by occluding the heterosexual. Pasternack and Ruth Mazo Karras have demonstrated that the monastic ideal of chastity is a sexual orientation (Karras, 2017, 38, 57-75). I argue that in monastic texts, 
3 'dulcia natorum pignora, nesciens coniugii

illecebrosa consortia, fetosa quadam suauissimi suci concretione producit: ecclesia uero bis acuto testamentorum mucrone hominum uitaliter corda transuerberans hereditariam legitimae aeternitatis sobolem casto uerbi fecundat semine' (Aldhelm, 2001, §V). particularly Ælfric's, there emerges an Old Testament heterosexual orientation; that is, a set of endorsed and tolerated practices, including circumcision, polygamy, priestly marriage, and feminine adornment, specific to the Old Testament and oriented around ensuring the continued survival and distinctive identity of the Jewish people. This orientation is not in itself sinful, but it is superseded by the Christian ideals of monastic chastity and universal membership. As Karma Lochrie has influentially noted, the medieval Christian West was not characterized by a normative heterosexuality. However, the cluster of 'cultural appurtenances' ('the sexual act of intercourse, the social and legal rights of marriage, ideas of domesticity, doctrines of procreation, concepts of parenting and child rearing,' and so forth) that Lochrie and other queer theorists describe as coalescing into heterosexuality as late as the Victorian era appears in late AngloSaxon writing in the form of Jewish (Old Testament) sexuality (Lochrie, 2005, xiii). The Anglo-Saxons, in other words, although neither heterosexual or homosexual themselves, had already invented a heterosexual Other.

\section{Aldhelm: Monastic Reproduction}

As a committed lifestyle with no equivalent in medieval Judaism or Islam, Christian chastity was an orientation to sexuality with its own pleasures and reproductive practices. As Pasternack has noted, the late seventh-century AngloLatin treatise De virginitate, by Aldhelm, Abbot of Malmesbury, portrays chastity as both pleasurable and fertile, qualities embodied in the figure of the bee, a scripturally authorized (according to Aldhelm) type of the Church who 'produces her sweet family and children, innocent of the lascivious coupling of marriage, by means of a certain generative condensation of a very sweet juice.' Just so, 'the Church, striking vitally into the hearts of men with the double-keen sword-edge of the (two) Testaments, fertilizes through the chaste seed of the Word the offspring who are lawful heirs of eternity' (Aldhelm, 1979, 62). ${ }^{3}$ In this form of generation, Ecclesia penetrates the Christian heart with a textual rather than sexual organ of fertilization. Also unlike a traditional phallus, this virginal organ is doubled rather than singular (bringing to mind Luce Irigaray's connection between doubled genitalia and textual femininity [Irigaray, 1985]); the Word it produces in lieu of semen is, as we well know, part of the masculine godhead. Queer reproduction, like much else in Aldhelm's extended complex of metaphors, resists a single reading: here the feminine penetrates, here chastity fertilizes, here Christians appear to be their own offspring. All tend not towards a static futurity but towards an excessive eternity. Celibacy, like the queer temporality proposed by José Esteban Muñoz, offers not just the rejection of heterosexual futurity and relationality, but also a potentially fuller and more loving existence than this one, a hopeful although by no means predetermined alternative futurity (Muñoz, 2009). 
The fruits of chaste reproduction are sweeter than worldly things: not only is this honey more delicious than 'all dishes of delicacies' (cuncta deliciarum) and more fragrant than 'sweet ambrosia and the odour of fragrant balsam, but [it] also [...] may exceed all delights of worldly sweetness and the exquisite pleasures of sumptuous gourmandising and may leave far beneath it the gulping down of sweet wine' (Aldhelm, 1979, 63). ${ }^{4}$ These delights lie beyond the reach of secular people engaged in reproductive sex. Nuns are the products of this spiritual conception, which is just as fruitful as sexual reproduction: they are 'adoptive daughters of regenerative grace brought forth from the fecund womb of ecclesiastical conception through the seed of the spiritual Word' (Aldhelm, 1979, 59-60) ['adoptiuas regenerantis gratiae filias ex fecundo ecclesiasticae conceptionis utero spiritualis uerbi semine progenitas'] (Aldhelm, 2001, §II). ${ }^{5}$ The Church reproduces as easily as, and with more pleasure than, the world of marriage and secular sin. As Weston notes, in portraying the reproductive monastery as a multi-celled honeycomb where bees gather together to joyfully share nectar, Aldhelm creates a 'sensuous fertility [that] is by definition communal and collective - and effectively homonormative' (Weston, 2003, 23).

Spiritual procreation and filiation are not merely metaphorical. To draw a binary distinction between constructed and biological forms of kinship is to ignore the importance of marriage, a non-biological voluntary relation, in creating heteropatriarchal families; the non-biological kin status of 'step-father' or 'father-in-law,' relations that enjoy full legal and social recognition, is as socially constructed as monastic fatherhood. Monasteries were in fact sites of child-rearing up to the tenth century, after which time they continued to foster and educate large numbers of adolescents. Indeed, V. A. Kolve has demonstrated twelfth-century monasteries' self-conception as potential sites of male maternal love for the boys within their care (Kolve, 1998, 1056-1059).

Such reproduction can be considered queer in the proper sense, since it arises out of the nonsexual love bonds within the body of the monastery. The idea of the monastery as queer space is hardly new. Kolve, Lochrie, Valerie Traub, and many others have noted the homoaffectivity of monastic communities, an affectivity that includes, in Carolyn Schroeder's words, both the 'presence of homoeroticism and anxieties about the homoerotic,' as well as sanctioned love bonds of various sorts between same-sex pairs (Schroeder, 2009, 333; Lochrie, 2005, 26-70; Traub, 2002, 62-65). Monastic life also allowed for the possibility of cross-sex pair-bonding without sexual expectations, reproduction, or any of the structures of marriage; some such couples were blood siblings like Benedict and Scholastica, but some were solely spiritual kin.

The queerness of monastic sexuality and affectivity is thus, in my view, not defined primarily by homoeroticism, however widespread, nor by the
4 'flagrantis ambrosiae thimiama ac nardi spirantis olfactum uincat, uerum etiam $[\ldots]$ uniuersam mundanae suauitatis dulcedinem opulentique luxus exquisita superet oblectamenta et haustum defruti despiciat' (Aldhelm, 2001, $\S \mathrm{VI})$.

5 In this analogy, the Word impregnates the fertile Church. See Lees and Overing (2001, 111-124) for an extensive feminist reading of this passage. 
6 See Lees and Overing (2001, 127-132) for the thematic connections between $D e$ virginitate and the homilies of Ælfric. homoaffectivity that, as C. Stephen Jaeger has amply demonstrated, suffused secular as well as religious aristocratic life (Jaeger, 1999). Nor indeed is it defined by non-normativity, queerness's now ubiquitous gloss, which we would have to measure by making the secular life ascendant and the regular life abject. I locate this queerness, instead, in the absolute orientation away from biological reproductivity and its secular institutions, and the formation of other durable kinship and affective structures against which, even when they appear ritually or superficially similar, the patriarchal reproductive family seems a pale and undesirable alternative. This is a definition of queerness that many queers of late twentieth-century North America would surely recognize, and which persists as an impulse even within a twenty-first-century queer population whose increasing access to majority rights has made LGBT and non-LBGT families seem increasingly similar.

\section{Jewish Heterosexuality: The Dangerous Example of Married Priests}

The Benedictine writers demonstrate that heterosexuality is outmoded by aligning sexual difference with Jewish-Christian difference, to be explicitly understood as temporal difference. The Old Testament endorses universal heterosexual marriage, both monogamous and polygynous, as well as the overlapping practice of concubinage. As a result, Aldhelm allows that for 'men of ancient times' ['ueteribus uiris'], 'the licence of the ancient law benignly permitted nuptial bonds of marriage for the sake of a family of offspring and for propagating the progeny of descendants' (Aldhelm, 1979, 78) ['priscae legis licentia nuptiales thalamorum copulas pro nepotum prosapia et posterorum progenie propaganda clementer indulsit'] (Aldhelm, 2001, §XXII). The virgins of this time are like virtuous pagans, praiseworthy in part because they dwelled in the 'darkness of dense night' (Aldhelm, 79, 1979) ['crassae noctis caliginem'] (Aldhelm, 2001, §XXII) before the new dispensation. The prolific translator and pedagogue Ælfric, Abbot of Eynsham, exploits this ideological inheritance in his work on Old Testament priesthood, ultimately developing a model of justified Jewish heterosexuality to which Christian celibacy is a natural and superior successor.

In Ælfric’s First Old English Pastoral Letter to Wulfstan, Archbishop of York (1006), which focuses largely on chastity and the problem of clerical sexuality, Ælfric demonstrates how central clerical chastity is to Christian difference from the Jewish past, and how central this difference is, in turn, to Christian knowledge. ${ }^{6}$ Characteristically, he exhorts, 'Ge sceolan witan, gif ge wisdom lufiað, hwæt sy betwux pam twam gecyðnyssum, pære ealdan æx, ær Cristes tocyme, and pære niwam gecyðnysse ...' ['You should know, if you love wisdom, what is between these two testaments: the old law, before Christ's advent, and 
the new testament'] (Fehr, [1914] 1966, IV, §19). ${ }^{7}$ Knowing the difference, knowing it as temporal difference, is crucial if one is to know anything of value.

The problem at hand is priestly marriage, which its practitioners apparently justify with recourse to Biblical example (or which Ælfric fears they will justify in this way): 'Nu mæg eape getimian, pæt eower sum ahsige, hwi he ne mote wif habban, swa-swa Aaron hæfde' ['Now it might easily happen that one of you asks why he may not have a wife just as Aaron had'] (Fehr, [1914] 1966, IV, $\S 147)$. The solution is a full supersessionary understanding of the difference between Jewish priests and their Christian successors:

Ponne secge we eow, pæt seo ealde $æ$ wæs ær Cristes to-cyme eall getacniendlic. And hi pa wif hæfdon, forpon-pe hi wæron flæsclice and hi næfre ne mæssedon and mihton pa swa don. Nu is seo ealde $æ$ eall awend on oper to gastlican pingum, and Godes penas sceolon healdan hyra clænnysse, swa-swa Crist hit astealde. And se-pe nu hilt ba ealdan $æ x$ fter Cristes tocyme on pa ealdan wisan, he bið amansumod... (Fehr, [1914] 1966, IV, §148-151)

[Then we say to you that before Christ's advent the old law was all symbolic. And they had wives then because they were carnal, and they never performed mass and could do it then. Now the old law is subsequently changed entirely to spiritual matters, and God's ministers must keep their chastity [clcennysse] just as Christ established it. And anyone who now keeps the old law in the old way after Christ's advent, will be excommunicated]

Giorgio Agamben's conception of (Franciscan) monasticism as a unique forma vitae that 'attempt[s] to realize a human life and practice absolutely outside the determinations of the law' (Agamben 2013, 110, emphasis removed) explains in part why these practices under the Old Law are so inadequate to monastic life: they represent a biofamilial management of desire and reproduction from which the religious body must utterly withdraw. The carnality of the old law and its practices both rhetorically excuses the marriages of Old Testament priests and implicitly institutes a prohibition on using practitioners of the old law as sexual role models.

Ælfric describes contemporary clerical marriage as a theological error, when those who 'nu hilt pa ealdan $æ x$ fter Cristes tocyme on pa ealdan wisan' demonstrate a profound misunderstanding of Christian temporality. The present is here doubly free of Jewish carnality - liberated both by its chronological place in revelation history ('æefter Cristes tocyme') and by its participation in the extended 'nu' of what Agamben calls messianic time (Agamben, 2005). The doubleness of this formulation - its doubled doubleness - is not a matter purely of emphasis or rhetorical flourish but of the compounded error of keeping the old law in the old way, without the exegetical understanding that would transform it into the liberatory law of chastity. As Kathleen Davis notes,
7 All translations from Old English, unless otherwise noted, are my own. I omit some editorial marks when quoting modern editions of medieval texts. 
8 See Hill (2005).

9 See Trilling (2007, 58-59) on the usefulness of this rhetoric.
'Periodization, if it is to have a historical legacy, results from a double movement: the first, a contestatory process of identification with an epoch, the categories of which it simultaneously constitutes $[. .$.$] and the second a rejection$ of that epoch identified in this reduced, condensed form' (Davis, 2008, 30-31). Ælfric's repetitions underscore the process by which he reifies the time of Mosaic law in order to reject it in favor of a cordoned-off Christian present.

Compare this emphasis on theological and temporal error to Wulfstan's later formulation of clerical marriage as adultery, filth, and evil, and his particular vilification of priest's wives, who wear the jewels that belong to the altar: 'Nis preostes cwene ænig oðer ping butan deofles grin' ['A priest's wife is nothing except a devil's snare'] (Jost, 1959, §166). In revising Ælfric's letter for his own pastoral use, Wulfstan excised the above portion explaining the difference between old and new law (Fehr, [1914] 1966). ${ }^{8}$ Wulfstan's location of conjugal temptation in women as sexual objects, and Ælfric's attribution of the sin to theological error, are characteristic of the treatment of sexuality in their work: while Wulfstan typically condemns shocking sexual sins as widespread, ${ }^{9}$ Ælfric's many discussions of chastity generally treat illicit sexual activity as characteristic of the especially perverse - evil tyrants seeking the virginity of saintly Christians, etc. - and the spiritually ignorant. As Clare Lees's reading of Ælfric demonstrates, the homilist hardly relishes discussing sexual activity, however licit, involving secular Christian women (Lees, 1999, 136). Regardless of any other reasons for this difference, as a rhetorical strategy it dovetails nicely with Ælfric's perpetual recuperation of the past as exemplum; while Jewish heroes participate in licit heterosexuality, pagan villains exemplify illicit and unruly sexuality.

Yet the carnality of the old law does not fully explain why those priests, holiest of their own age, married. The answer is found in Jewish particularity:

Pa moste se Aaron and his æfter-gengan niman him to gemacan, æfter Moyses $æ$ an clæne mæden. Forban-pe nan ne moste of oprum cynne becuman to pæm hade, pæt he bisceop wære, butan of Aarones cynne. Hi ne mostan na wifian on nanre wudewan ne on forlætenan wife be Godes leafe pa, ac on clænum mædene. And hyra clænnysse healdan, swa oft swa hi offredon pa ælican onsægdnysse. Hy moston pa wel wif habban, pæt ne wurde ateorad pæt mære bisceop-cyn, pe com of Aarone. Forban-pe nan cyn ne moste becuman to bam hade butan pæt an cyn pe com of Aarone. And hit stod æfre swa on pære ealdan æ. (Fehr, [1914] 1966, IV, §128-134)

[Then, according to Moses's law, Aaron and his descendants had to marry clean maidens, because no one from another line could attain the rank of bishop, except from Aaron's line. They could not by God's permission marry any widow or abandoned wife then, only clean maidens, and maintained their cleanness as often as they offered the lawful sacrifice. 
They might well have wives then, so that the illustrious line of bishops that came from Aaron did not flag, because no group could attain that rank except for the line that came from Aaron. And so matters always stood according to the Old Law.]

The purpose of these marriages was the physical continuation of the priestly tribe; 'bæt mære bisceop-cyn, be com of Aarone' represents an ethnic view of the priesthood, the ecclesiastical structure proper to Old Testament Jews. Ælfric is careful to incorporate a vision of these priests as sexually restrained in their own way - marrying only virgins - in order to procreate. Through this vision, Ælfric extends the descriptor 'clæne' to priests' wives, the very group Wulfstan describes as worthless except as vehicles for temptation ('butan deofles grin'). Cleanness then describes not only continent married women - a conventional if somewhat less common use - but also priests who are, at the appointed times, sexually active with such women. That both groups are also Jewish not only extends the unconventionality of this move, for neither group is under Christ's umbrella, but also provides its mitigating logic - these guardians of the old law were clean in their way, in their time. As both Daniel Anlezark and Catherine Karkov note, Ælfric transforms Abraham's sexuality according to the same logic; his translation of Genesis, for instance, downgrades Abraham's polygamous wife Hagar to concubine (cyfese), omitting the explicit reference to marriage, and rationalizes his now properly hierarchized sexual relationships in terms of his sacred fatherhood, which makes a Christian future (and other futures) possible (Anlezark, 2000, 195-196; Karkov, 2016, 208; Marsden, 2008, Genesis 21.12). Jewish sexual difference is not absolute, nor is it a difference among kinds and combinations of bodies and pleasures. It is difference in time - old sexual law, new sexual law - and in ideology. By explaining priestly marriage and priestly celibacy as two parallel but not equivalent holy paths, one old, Jewish, and procreative, and the other new, Christian, and non-reproductive, Ælfric describes two incommensurable sexual orientations.

\section{Purity in Translation}

While patristic and medieval Christian writings tend to portray early Christians as rejecting Jewish forms of holiness, in fact the New Testament's debates on food purity and circumcision focus on the inclusion of Gentile Christ-followers under the social umbrella of Jewish purity. ${ }^{10}$ Instead of rejecting Jewish ideas of purity and impurity, the New Testament largely translates this distinction from

10 See Freidenreich (2011, 87-100). the physical realm to the spiritual. This shift is particularly clear in the Vulgate. In Latin versions of the Old Testament, mundus and inmundus ['clean' and

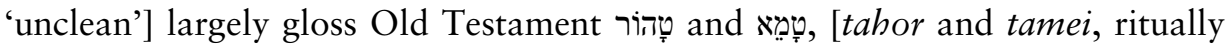


11 This work is more commonly known as the Old English Hexateuch, since Joshua does not appear in its illuminated (and therefore relatively wellknown) witness British Library, Cotton MS Claudius B.iv.

12 See Marsden (1995, 402-439) on the Latin sources of the Old English Heptateuch.

13 See Momma (2003, 60).

14 Throughout this essay, I use Ælfric's preferred spelling of cloennyss. 'pure' and 'impure']; they appear most often in the context of the holiness code that regulates eating, sacrifice, the containment and expression of bodily fluids, handling of the dead, and so forth in the life of ancient Israel. In the New Testament, on the other hand, the words typically emerge in expressions such as Beati mundo corde ['Blessed are the clean of heart'] (Matthew 5:8) and immundus spiritus ['unclean spirit,' i.e., demon] (Matthew 12:43, Luke 11:24, etc.), glossing forms of Greek $\kappa \alpha \theta \alpha \rho o ́ \varsigma$ and $\dot{\alpha} \kappa \alpha \dot{\theta} \theta \rho \tau o \varsigma$ [katharós and akáthartos, 'clean' and 'unclean']. The continuity between Old and New Testament forms of mundus/inmundus arises authentically from the Biblical Greek, for $\kappa \alpha \theta \alpha \rho o ́ s$ and $\dot{\alpha} \kappa \alpha \dot{\alpha} \theta \alpha \tau \sigma \varsigma \varsigma$ are also, within the Septuagint, the translated forms of טָמֵא

Ælfric, primary Old English translator of the Old Testament, translates the Vulgate's mundus and inmundus into Old English cloene and unclone. When translating Genesis in the Old English Heptateuch, an eleventh-century composite translation of the Pentateuch, Joshua, and Judges, he does this in 7:2 and 8:20 when referring to clean and unclean beasts (Marsden, 2008). ${ }^{11}$ In contrast, other Old English translators shy away from linking clcennyss to the Old Testament. For example, although the concept pervades (and indeed organizes) the Book of Leviticus and the word inmundus (as immundus and its declensions) appears approximately 60 times in the Vulgate Leviticus, this word is translated only once into the Old English Heptateuch's version of Leviticus, which is not attributed to Ælfric, in regards to prohibited fish: 'Ne ete ge nanne fisc, buton ba pe habbað finnas and scilla; ba oðre synd unclæne' ['Do not eat any fish except those that have fins and scales; the others are unclean'] (Marsden, 2008, 133; Leviticus 11.9-12). ${ }^{12}$ Within the Heptateuch, Ælfric was the primary translator of Genesis 1-3, 5:32-9:29, and 12:1-24:26; Numbers 13-26; Joshua; and Judges; the other sources provided the remainder and a few emendations and interpolations (Clemoes, 1974, 48; Marsden 2000, 2008). Not a single immundus is translated from the Latin Numbers or Deuteronomy, where the word is abundant, or from Joshua or Judges, where it is scarce, into Old English. Ælfric, apparently responsible for many of these omissions, does translate two of the three instances in which the beasts on Noah's ark are separated into clean and unclean (Genesis 7:2, 8:20). In contrast, Old Testament poems pointedly avoid not only the word but also the concept: Genesis A refers not to clean and unclean beasts on the ark but to 'ælcum æefter agenum eorðan tudre' ['each after its terrestrial kind'] (Anlezark, 2011, 1. 1305), while the Biblical heroine Judith's devotion to Jewish dietary law, a crucial plot point in the Biblical narrative and in Ælfric's prose translation of the story, is nowhere in the poem. ${ }^{13}$

Vernacular writers instead use clcennyss to translate a cluster of Latin synonyms for chastity, including castitas, pudicitia, caelibatus, and pudor (Cameron, 2016, s.v. 'clēennes'). ${ }^{14}$ In Ælfric's context and in Old English generally, cloennyss tends to mean 'chastity': in Benedictine homiletics, as Pauline Stafford and Charles D. Wright have observed, it is primarily associated 
with clerical or sanctified chastity (Stafford, 1999, 7; Wright, 2007, 252). Within the poetic corpus, cloene nearly always means morally or sexually pure; more often than not, it refers to Mary's virginity or the chastity of a saint. In Ælfric's works, clonnyss can be more broadly defined, in Shannon O. Ambrose's terms, as 'spiritual and bodily purity’ (Ambrose, 2014, 8). Ælfric is in fact the main vernacular source for this term in its various forms - as Ambrose notes, he uses the terms clannyss and unclonnyss more than 55 times in the homilies alone (Ambrose, 2014, 6).

In Ælfric's writing and in the Anglo-Saxon corpus as a whole, cloennyss is inseparable from the valorization of monastic celibacy and saintly virginity. Yet in his discussion of Old Testament priests and their wives, women he optimistically calls cloen [e] moden[u] rather than deofles grin, Ælfric expands the term's remit across both temporal and sexual difference. Jews, by means precisely of their relegation to a superseded model of the law, can now receive the appellation cloene, an ordinarily Christian sexual and spiritual term, for their own historically sufficient arrangements.

Unlike those Heptateuch translators who would avoid using cloene or clonnyss to describe Jewish ritual purity, perhaps in order to avoid any confusion with Christian spiritual and sexual purity, Ælfric finds a reason to grant a kind of vernacular theological dispensation to those benighted Jews whose reproductive heterosexuality, in the darkness before the New Dispensation, made Christ's birth ultimately possible. Ælfric thus transmutes Jewish purity into Christian sexual purity. Terms from the Hebrew Bible that, when translated into Greek and Latin, assume equivalence to New Testament terms for spiritual purity thus undergo a further conversion in the writings of Ælfric, who diverges from other Old English writers in linking the word cloene not only with the Old Testament but also, specifically, with Jewish sexuality. Ælfric's linguistic choices forge a largely fictive continuity between Jewish and Christian sexual purity systems, while also authorizing their decisive temporal break, ultimately a break between heterosexual and monastic kinship systems. In urging priests to understand this temporal, sexual, and ethnic difference as the basis for wisdom, Ælfric founds his pastoral care upon a simple message: heterosexual kinship and its trappings are on the wrong side of history.

\section{Acknowledgements}

I wish to thank the many colleagues who have offered feedback on these ideas. I am particularly grateful to Vin Nardizzi. 


\section{About the Author}

Mo Pareles is Assistant Professor of English at the University of British Columbia, where she is a member of the Oecologies collective. Her current book project is Translating Purity: Jewish Law and the Making of Difference in Old English Literature (Email: mo.pareles@ubc.ca).

\section{References}

Agamben, G. 2013. The Highest Poverty: Monastic Rules and Form-of-Life, trans. A. Kotsko. Stanford, CA: Stanford University Press.

Agamben, G. 2005. The Time That Remains: A Commentary on the Letter to the Romans, trans. P. Dailey. Stanford, CA: Stanford University Press.

Aldhelm of Malmesbury. 2001. Aldhelmi Malmesbiriensis Prosa de Virginitate cum Glosa atque Anglosaxonica, ed. S. Gwara. CCSL 124A. Turnhout, Belgium: Brepols.

Aldhelm of Malmesbury. 1979. Aldhelm: The Prose Works, trans. M. Lapidge and M. Herren. Cambridge, UK: D. S. Brewer.

Ambrose, S.O. 2014. The Theme of Lay Clannyss in Ælfric’s Letters to Sigeweard, Sigefyrð and Brother Edward. Mediaevalia 35: 5-21.

Anlezark, D. 2000. An Ideal Marriage: Abraham and Sarah in Old English Literature. Medium Aevum 69: 187-210.

Anzelark, D., ed. and trans. 2011. Old Testament Narratives. Cambridge, MA: Harvard University Press.

Berlant, L. 1997. The Queen of America Goes to Washington City: Essays on Sex and Citizenship. Durham, NC: Duke University Press.

Boyarin, D. 1994. A Radical Jew: Paul and the Politics of Identity. Berkeley, CA: University of California Press.

Boyarin, D. 1997. Unheroic Conduct: The Rise of Heterosexuality and the Invention of the Jewish Man. Berkeley, CA: University of California Press.

Davis, K. 2008. Periodization and Sovereignty: How Ideas of Feudalism and Secularization Govern the Politics of Time. Philadelphia, PA: University of Pennsylvania Press.

Deleuze, G. and F. Guattari. 2004. A Thousand Plateaus, trans. B. Massumi. London: Athlone.

Cameron, A., A.C. Amos, A.D. Healey, et al., 2016. Dictionary of Old English: A to H online. Toronto, ON: Dictionary of Old English Project, University of Toronto. http:// www.doe.utoronto.ca.

Clemoes, P. 1974. The Composition of the Old English Text. In The Old English Illustrated Hexateuch, ed. C.R. Dodwell and P. Clemoes, 2-37. Copenhagen, Denmark: Early English Manuscripts in Facsimile.

Edelman, L. 2004. No Future: Queer Theory and the Death Drive. Durham, NC: Duke University Press. 
Fehr, B., ed. [1914] 1966. Die Hirtenbriefe Elfrics in altenglischer und lateinischer Fassung. Hamburg, Germany: Henri Grand. Darmstadt, Germany: Wissenschaftliche Buchgesellschaft.

Ferguson, R.A. 2004. Aberrations in Black: Toward a Queer of Color Critique. Minneapolis, MN: University of Minnesota Press.

Foucault, M. 1996. Friendship as a Way of Life, trans. J. Johnston. Foucault Live: Collected Interviews, 1961-1984, ed. S. Lotringer, 308-312. New York: Semiotext(e).

Freidenreich, D.M. 2011. Foreigners and their Food: Constructing Otherness in Jewish, Christian, and Islamic Law. Berkeley, CA: University of California Press.

Hill, J. 2005. Authorial Adaptation: Ælfric, Wulfstan, and the Pastoral Letters. In Text and Language in Medieval English Prose: A Festschrift for Tadao Kubouchi, ed. A. Oizumi, J. Fisiak, and J. Scahill, 63-75. Frankfurt am Main, Germany: Peter Lang.

Irigaray, L. 1985. This Sex Which is Not One, trans. C. Porter. Ithaca, NY: Cornell University Press.

Jaeger, C.S. 1999. Ennobling Love: In Search of a Lost Sensibility. Philadelphia, PA: University of Pennsylvania Press.

Jost, K., ed. 1959. Die 'Institutes of polity, civil and ecclesiastical': ein Werk Erzbischof Wulfstans von York. Bern, Switzerland: Francke.

JPS Hebrew-English Tanakh: The Traditional Hebrew Text and the New JPS Translation. [1985] 1999. 2nd ed. Philadelphia, PA: Jewish Publication Society.

Kahan, B. 2013. Celibacies: American Modernism and Sexual Life. Durham, NC: Duke University Press.

Karkov, C.E. 2016. Hagar and Ishmael: The Uncanny and the Exile. In Imagining the Jew in Anglo-Saxon Literature and Culture, ed. S. Zacher, 197-218. Toronto, ON: University of Toronto Press.

Karras, R.M. 2017. Sexuality in Medieval Europe: Doing Unto Others. 3rd edn. New York: Routledge.

Kruger, S.F. 2006. The Spectral Jew: Conversion and Embodiment in Medieval Europe. Minneapolis, MN: University of Minnesota Press.

Kolve, V.A. 1998. Ganymede/Son of Getron: Medieval Monasticism and the Drama of Same-Sex Desire. Speculum 73: 1014-1067.

Lees, C.A. 1999. Tradition and Belief: Religious Writing in Late Anglo-Saxon England. Minneapolis, MN: University of Minnesota Press.

Lees, C.A. and G.R. Overing. 2001. Double Agents: Women and Clerical Culture in AngloSaxon England. Philadelphia, PA: University of Pennsylvania Press.

Lochrie, K. 2005. Heterosyncracies: Female Sexuality When Normal Wasn't. Minneapolis, MN: University of Minnesota Press.

Marsden, R., ed. 2008. The Old English Heptateuch and Ælfric’s Libellus de veteri testamento et novo. Oxford, UK: Early English Text Society.

Marsden, R. 2000. Translation by Committee?: The 'Anonymous' Text of the Old English Hexateuch. In The Old English Hexateuch: Aspects and Approaches, ed. R. Barnhouse and B.C. Withers, 41-90. Kalamazoo, MI: Medieval Institute.

Marsden, R. 1995. The Text of the Old Testament in Anglo-Saxon England. Cambridge, UK: Cambridge University Press.

Momma, H. 2003. Epanalepsis: A Retelling of the Judith Story in the Anglo-Saxon Poetic Language. Studies in the Literary Imagination 36: 59-73. 
Muñoz, J.E. 2009. Cruising Utopia: The Then and There of Queer Futurity. New York: New York University Press.

Pasternack, C.B. 2004. The Sexual Practices of Virginity and Chastity in Aldhelm's De Virginitate. In Sex and Sexuality in Anglo-Saxon England: Essays in Memory of Daniel Gilmore Calder, eds. C.B. Pasternack and L.M.C. Weston, 93-120. Tempe, AZ: Arizona Center for Medieval and Renaissance Studies.

Saltzman, B.A. 2011. Writing Friendship, Mourning the Friend in Late Anglo-Saxon Rules of Confraternity. Journal of Medieval and Early Modern Studies 41: 251-291.

Schroeder, C.T. 2009. Queer Eye For The Ascetic Guy? Homoeroticism, Children, and the Making of Monks in Late Antique Egypt. Journal of the American Academy of Religion 77: 333-347.

Stafford, P. 1999. Queens, Nunneries, and Reforming Churchmen: Gender, Religious Status, and Reform in Tenth- and Eleventh-Century England. Past and Present 163: 335.

Symons, D.T., ed. and trans. 1953. Regularis Concordia Anglicae Nationis Monachorum Sanctimonialiumque: The Monastic Agreement of the Monks and Nuns of the English Nation. New York: Nelson.

Traub, V. 2002. The Renaissance of Lesbianism in Early Modern England. Cambridge, UK: Cambridge University Press.

Trilling, R. 2007. Sovereignty and Social Order: Archbishop Wulfstan and the Institutes of Polity. In The Bishop Reformed: Studies in Episcopal Power and Culture in the Central Middle Ages, eds. J.S. Ott and A.T. Jones, 58-85. Aldershot, UK: Ashgate.

Venarde, B.L., ed. and trans. 2011. The Rule of Saint Benedict. Cambridge, MA: Harvard University Press.

The Vulgate Bible: Douay-Rheims Translation. 2010-13. Eds. S. Edgar and A.M. Kinney, 6 vols. Cambridge, MA: Harvard University Press.

Weston, L.M.C. 2003. Queering Virginity. Medieval Feminist Forum 36: 22-24.

Weston, L.M.C. 2011. Where Textual Bodies Meet: Anglo-Saxon Women's Epistolary Friendships. In Fundamentals of Medieval and Early Modern Culture: Friendship in the Middle Ages and Early Modern Age: Explorations of a Fundamental Ethical Discourse, eds. A. Classen and M. Sandidge, 231-246. Berlin, Germany and Boston, MA: De Gruyter.

Wright, C.D. 2007. A New Latin Source for Two Old English Homilies (Fadda I and Blickling I): Pseudo-Augustine, Sermo App. 125 and the Ideology of Chastity in the Anglo-Saxon Benedictine Reform. In Source of Wisdom: Studies in Old English and Early Medieval Latin in Honour of Thomas D. Hill, eds. C.D. Wright, T.N. Hall, and F. M. Biggs, 239-265. Toronto, ON: University of Toronto Press. 